\title{
A LEGJELENTŐSEBB HAZAI FÜRDŐVÁROSOK TELEPÜLÉSSZERKEZETI JELLEMZŐINEK VIZSGÁLATA
}

\author{
KÖBLI ÁDÁM - HORVÁTH ZOLTÁN \\ A STUDY OF THE CHARACTERISTICS OF THE MOST SIGNIFICANT \\ HUNGARIAN SPA TOWNS \\ BASED ON THEIR SETTLEMENT STRUCTURE
}

\begin{abstract}
In our research we investigate the complex settlement characteristics and specialities of the best-known Hungarian spa cities - Bük, Gyula, Harkány, Hajdúszoboszló, Hévíz, Sárvár and Zalakaros - that attract the most guests and offer the highest standard in accordance with the suprastructure of health tourism. These settlements have outstanding valuable tourism traditions, where the current structure was created over many decades. The spa cities carry out certain improvements continuously in order to maintain their leading role within the health tourism market. However, these developments should be planned in a complex way, with enhanced protection of natural resources, by emphasizing the importance of a system approach. Harmonious and sustainable development can therefore be accomplished in the long run, and can preserve local conditions, primarily ecological unity and the health of the specific mineral water base. In addition, planning based on local conditions and the priority of the interests of the local communities can also lead spa cities toward conscious long-term sustainability. These particularities have an effect on the settlement structure of the spa cities, the research of which ensures new opportunities in the conscious developments of the settlements.
\end{abstract}

Keywords: spa towns, settlement structure, GIS, Hévíz, Sárvár

\section{Bevezetés}

Magyarország nemzetközileg is elismert, értékes hagyományokkal rendelkező turisztikai desztinációi közül kiemelkednek a fürdővárosaink, amelyekben magas minőségú egészségturisztikai szolgáltatások fogadják a vendégeket (JóNÁS-BERKI M. et al. 2014). Hazánkban a gyógyvizek és termálvizek kimagasló mennyiségben és minőségben fordulnak elő, ezért a fürdőzés, a fürdőkultúra komoly tradíciókkal rendelkezik (CSIFFÁRY G. 2004, KósA L. 1999).

A turizmus olyan komplex társadalmi-gazdasági tevékenység, amely szinte valamenynyi gazdasági ágazat tevékenységéből áll össze. Ennek előnyei a kooperációs lehetőségek és a hatékonyság, amelynek révén egy rugalmas és kreatív rendszer jön létre (HAJNAL K. 2010). Az összetettsége miatt azonban a turizmus sérülékeny is. Globális-lokális gazdasági hatások és társadalmi változások jelentős negatív hatásokat tudnak okozni a turizmusban, ezt a jelenleg is zajló járványhelyzet, illetve az ezzel járó utazási korlátozások is bizonyítják, amelyek minden hazai települést, így a fürdővárosokat is kiemelten érintik.

Az elmúlt évtizedek nagyütemú fürdőfejlesztései révén sok település épített fürdőt és kezdte el a turizmus komplex térségi fejlesztését (BAKuCz M.-Tegzes A. 2016, Hustiné BÉRES K. 2011, ZSARNÓCZKY M. B. 2017). Napjainkban azok a települések tekinthetők hazánkban hosszú távon sikeres fürdővárosoknak, amelyek korábbi és jelenlegi fejlesztéseik által jelentôs belföldi és külföldi vendégkörre tettek szert (GALAMBOS I. et al. 2015). A beteg vendégeknél a gyógyulás lehetősége, míg az egészségesek részéről a megelőzés, a 
prevenció a fő motiváció, amely állandó keresletet jelent. Ráadásul az egészséges életmód népszerúsödésével, a civilizációs betegségek terjedésével és az alternatív gyógymódok általánosabbá válásával ez a kereslet fokozatosan növekszik (SMITH, M.-PuCZKó L. 2010). A városi és turisztikai fejlesztések, a megjelenő új szolgáltatások és infrastrukturális beruházások együttesen és multiplikátor módon fejtik ki hatásukat (Nemzeti Turizmusfejlesztési Stratégia 2030, 2017).

Vizsgálataink még a járványhelyzet előtti időszakban készültek el. Természetesen a 2020-as év történései alapvetően változtatták meg a turisztikai szektor jelenlegi helyzetét és egyelőre nehéz megjósolni, mikor és milyen formában térhet vissza az ágazat korábbi állapotába. Ezzel együtt nem kérdés, hogy ha újra lehet majd szabadon és biztonságosan utazni, az egészségturisztikai motiváció továbbra is az elsődleges szempontok közt foglal majd helyet a turisták célterület-választásában.

\section{Célkitúzés és módszertan}

Tanulmányunkban a legismertebb, legtöbb vendéget vonzó és legmagasabb minőséget nyújtó magyar fürdővárosok - Bük, Gyula, Harkány, Hajdúszoboszló, Hévíz, Sárvár és Zalakaros - komplex városszerkezeti jellemzőit és sajátosságait vizsgáljuk az egészségturizmus szuprastruktúrájával összhangban. A tanulmányban bemutatott elemzés része egy nagy komplex fürdőváros-fejlesztési kutatásnak (KöBLI Á. 2018), amelynek célja egy olyan összehasonlító vizsgálat, aminek a révén egy közös, fenntartható és tudatos döntéseket támogató általános fejlesztési modell megalkotása válik lehetôvé a hazai fürdővárosokat illetően. Ennek egyik elemeként fontos megismerni az egészségturizmusnak a településmorfológiára gyakorolt hatásait, a különböző funkciók térbeli elhelyezkedését. A településeken a jelenlegi szerkezet hosszú évtizedek alatt jött létre. A fejlesztési dokumentumok és a szakmai interjúk feldolgozása során ugyanaz a kutatói kérdés merült fel újra és újra a legsikeresebb hazai fürdővárosokat illetően, miszerint létezik-e önmagában gyógyhelyfejlesztés, elegendó-e csupán a minőségi egészségturizmus és egy sikeres gyógyfürdő megléte a városi funkciók bővüléséhez, vagy több egyéb kiegészító ágazat szükséges-e a hosszú távú fejlődéshez és a települések stabilitásához.

Célunk bemutatni a nemzetközi jelentőségú fürdővárosok városszerkezeti felépítését kereskedelmi szálláshelyeinek kapacitása (férőhely) és típusa, valamint a fő vonzerők elhelyezkedése alapján. Ezeket összevetjük a területhasználat típusaival, a különböző ágazatok (kiemelten az ipar) települési szerkezetével, amelynek adatai az OpenStreetMap adatbázisból származnak. A magánszálláshelyeket azok kimagasló száma miatt (például Hajdúszoboszlón 1294 fő a vendéglátók száma, KSH 2018) nem jelöltük az ábrák áttekinthetősége érdekében, de a szöveges jellemzésben kitérünk rá. A szálláshelyadatok a települési önkormányzatok szálláshely-nyilvántartásaiból származnak. A látnivalók esetén csak a legjelentősebb hatású attrakciókat ábrázoltuk két különböző kategóriában, amelynek osztályozásához a helyi turisztikai szakemberekkel készített interjúkat használtuk fel. Az ábrázoláshoz az ArcGIS programot használtuk.

Az elemzéshez szükséges adatokat részben saját korábbi fürdővárosi kutatásaink (KöBLI Á. 2015, HoRvÁTH Z.-KÖBLi Á. 2016, HoRVÁTH Z. et al. 2017a) és tapasztalataink biztosították, amelyek során több alkalommal készült helyi lakosokkal kérdőíves kutatás, illetve a települések életét meghatározó négy fő terület - önkormányzat, fürdő, szállodák, TDM - szereplőivel készültek szakmai interjúk (KöBLI Á. 2018). Emellett a hét település különböző fejlesztési koncepcióinak, terveinek szakszerû feldolgozása történt meg. Minden fürdôváros korszerú, innovatív tervekkel rendelkezik, amelyek elkészítése természetesen 
kötelező feladat, de mivel a tényleg sikeres és hatékony fejlesztések megvalósításához komoly anyagi lehetőségeik és hosszú távú érdekeik kötődnek, megpróbálják a sablonos megoldások mellett valódi tartalommal is megtölteni azokat.

Az egészségturizmus városszerkezetre gyakorolt hatásának bemutatása céljából a hét település esetén településmorfológiai térképeket szerkesztettünk, amelyek alapján négy jellemző csoportot tudtunk lehatárolni. Jelen tanulmányunkban a négy csoport 1-1 jellegzetes települését mintaterületként részletesebben is bemutatjuk. Ez a fajta térképi megjelenítés alkalmas az egészségturizmus települési hatásainak az összetett vizsgálatára, az eltérő települési funkciók térbeli mintázatainak ábrázolására. Jól szemlélteti a hét település karaktereiben eltérő sajátosságokat, mind a szálláshelyek és az attrakciók, mind a turizmus szempontjából kiemelt rekreációs és zöldterületek elhelyezkedését. A helyiek szempontjából fontos lakóhelyi területek viszonyát is bemutatja a turisztikai helyek függvényében, illetve az egyedi gazdasági lehetőségek, például az ipar településen belüli elhelyezkedését.

\section{A hazai fürdóvárosok tipizálása}

A településmorfológiai vizsgálat céljából hét esettanulmány készült, hét helyszín került kiválasztásra, ezek szakszerû lehatárolása újszerú megközelítést igényelt. A különböző fürdőfejlesztéseknek köszönhetően sok település rendelkezik fürdővel, de MichaLKó G.-RÁTz T. (2011) szerint hazánkban klasszikus értelemben vett fürdővárossal kevéssel találkozhatunk, mivel a gyógyturizmus uralkodó szerepe csak kevés településen tud lényegi, komplex települési hatásokat is okozni.

A magyar fürdővárosok nagyok sokszínúek, eltérő városi környezettel, történeti hagyományokkal és gazdasági szereppel rendelkeznek, ezért szükséges a vizsgált fürdők körének tudományos lehatárolása. A mai napig nem tisztázott ugyanis, hogy mely településeket hívhatjuk fürdővárosnak. Általában a jelentős gazdasági szerepet játszó termál- és gyógyfürdővel rendelkező települések esetében használjuk a fürdőváros elnevezést, de a mai napig a legaktuálisabb ágazati stratégiának tekinthető Országos Egészségturizmus Fejlesztési Stratégiában (OES 2007) csak a fürdőváros jelleg, mint cél jelenik meg a települések számára, konkrét értelmezése a fürdővárosnak nincs. Az OES ugyanis nem a települések, hanem a fürdőlétesítmények alapján készít kategorizálást. Budapest Főváros Kormányhivatala Népegészségügyi Főosztályának nyilvántartásai alapján összesen 103 minősített gyógyfürdő múködik hazánkban, ebből 13 Budapesten. A gyógyfürdők a hazai gyógyturizmus legfontosabb színhelyei, ahol a 74/1999. (XII. 25.) EüM rendeletnek megfelelően természetes gyógyvizeket használnak (kormanyhivatal.hu, 2021).

Az említett OES három szinten kategorizálta a hazai fürdólétesítményeket, és így a fürdőknek otthont adó településeket is. A kutatásban kimutatott 385 fürdőtelepülés közül 187-ben soroltak be létesítményt valamely kategóriába, amely alkalmas volt a fejlesztési célok megvalósításához. Három kategóriát határoztak meg:

- nemzetközi jelentőségú fürdőhelyek, történelmi, múemléki fürdők, gyógyhelyek;

- országos és regionális jelentőségú turisztikai szolgáltatók;

- helyi jelentőségú fürdők.

Ez a kategorizálás - főleg a jelentősebb fürdővárosok tekintetében - ma is megállja a helyét, így ezt vettük kutatásunk alapjának, felülvizsgálva és figyelembe véve a legújabb, 2017-es Nemzeti Turizmusfejlesztési Stratégia 2030 behatárolását is, ami alapvetően megegyezik ezzel a csoportosítással a legmagasabb szinteken. Az 1. ábra mutatja be a három kategóriába tartozó településeket. 


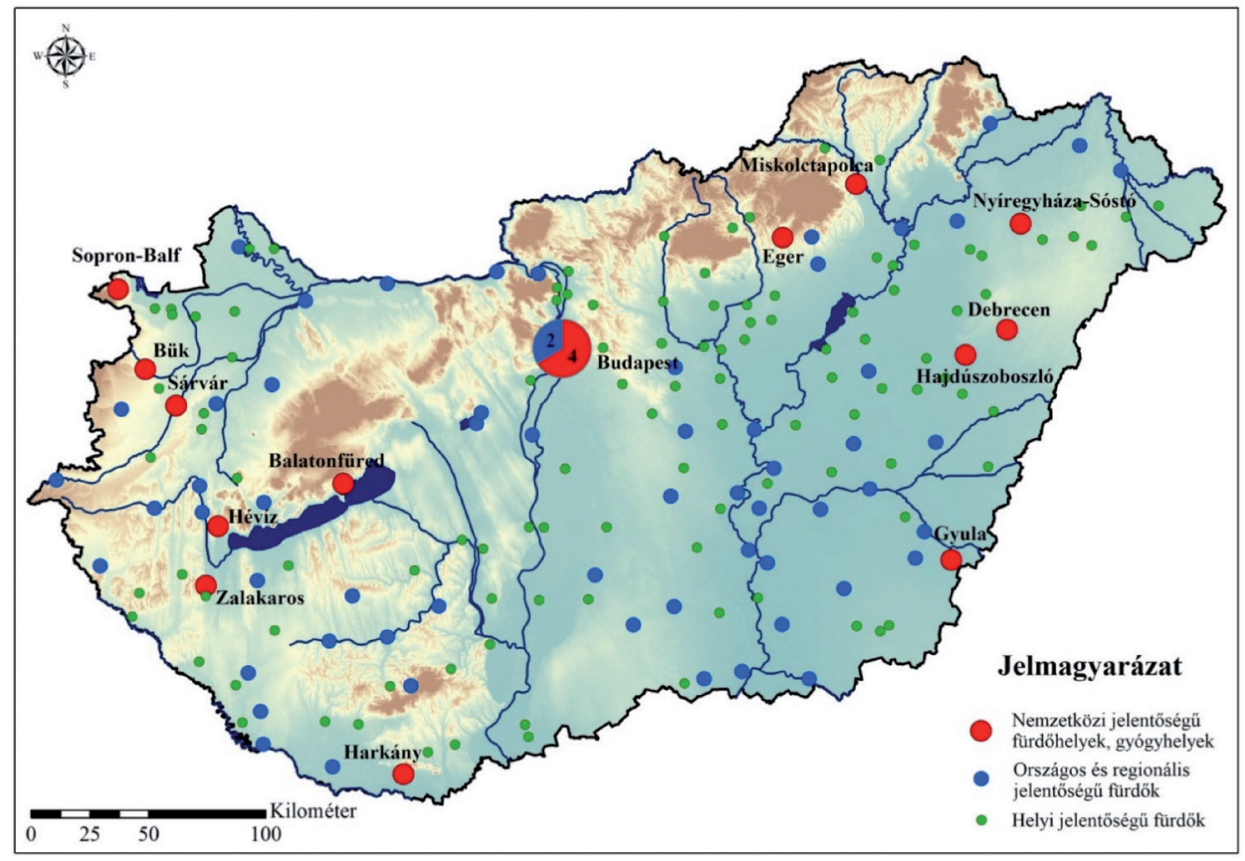

1. ábra A magyarországi fürdők kategóriák szerinti beosztása és elhelyezkedése (szerk. HORVÁTH Z. 2018, az OES 2007 alapján)

Figure 1 The classification and location of spas in Hungary (ed. by HORVÁTH, Z. 2018, based on OES 2007)

Az Országos Egészségturizmus Fejlesztési Stratégia (2007) által nyilvántartott Nemzetközi jelentôségü fürdőhelyek, történelmi müemléki fürdók, gyógyhelyek kategóriába 17 fürdőt soroltak (1. táblázat).

1. táblázat - Table 1

A legrangosabb kategóriába tartozó hazai fürdők (szerk.: KöBLI Á. 2018, az OES 2007 alapján)

The most prestigious spas in Hungary (ed. by KöBLI, Á. 2018, based on OES 2007)

Nemzetközi jelentóségú fürdőhelyek, történelmi, múemléki fürdők, gyógyhelyek

\begin{tabular}{lll} 
Balatonfüred & Hajdúszoboszló & Nyíregyháza-Sóstó \\
Bükfürdő & Harkány & Rudas Gyógyfürdő \\
Debrecen-Nagyerdő & Hévíz & Sárvár \\
Eger-Egerszalók & Lukács Gyógyfürdő & Sopron-Balf \\
Gellért Gyógyfürdő & Miskolc-Miskolctapolca & Széchenyi Gyógyfürdő \\
Gyula & & Zalakaros \\
\hline
\end{tabular}

A 17 fürdőnek otthont adó fürdővárosok azonos elvek szerinti vizsgálata és számukra közös fejlesztési tervek kidolgozása a települések eltérő karaktere, turisztikai és gazdasági súlya, hagyományai miatt azonban nem lehetséges, így további csoportosítás szükséges. 
A besorolt fürdők közül 4 - a Gellért Gyógyfürdő, a Lukács Gyógyfürdő, a Rudas Gyógyfürdő és a Széchenyi Gyógyfürdő - Budapesten található. Budapest sokszínú turizmusának egyik kiemelkedő és meghatározó jellemvonása gazdag és értékes gyógyvízkincse, fürdőkultúrája, ugyanakkor mégsem sorolható a klasszikus fürdővárosok közé, mivel a főváros vonzerő-összetettsége miatt nem mutatja az egészségturisztikai desztinációk sajátosságait (JóNÁS-BERKI M. et al. 2014), a főváros színes és szerteágazó turisztikai kínálatának csak egy kicsi, bár nagyon értékes része a kimagasló fürdőkultúra; emiatt nem került sor további vizsgálatára a tanulmányban.

Fentieket tehát nem számítva további 13 nemzetközi jelentőségű fürdőváros található Magyarországon, de ezek egységes szempontú vizsgálata még mindig nem lehetséges, ugyanis köztük több olyan közép- és nagyváros (Debrecen, Eger, Miskolc, Nyíregyháza) is található, amelyek turisztikai termékkínálatában a klasszikus városi turizmus mellett az egészségturizmus csak kiegészítő szerepet kap (JóNÁs-BERKi M. et al. 2014). Egyes nagyvárosokban sokszor csak bizonyos településrészekre terjed ki a fürdővárosi szolgáltatások és a miliő hatásköre, mint pl. Miskolctapolca vagy Nyíregyháza-Sóstó esetében, a város mindennapi életére, fejlődési lehetőségeire a helyi egészségturizmus csak kismértékben hat (KöBLI Á. 2018).

A fürdővárosok köre az egyes településeken megtalálható erős (az egészségturizmusnál is meghatározóbb) turisztikai termék és annak hatásai miatt további szűkítést igényel. Így pl. Balatonfüred gyógyászati hagyományai és fürdőkultúrája alapján mindenképpen az egyik legfontosabb hazai fürdőhelyünk, ám mivel a településen jellemző nyári, szezonális vízparti turizmussal alkot erôs, sikeres és nehezen elválasztható párost (MichalKó G.-RÁTz T. 2011), a fejlődését jobban meghatározza balatoni jellege, mint az egészségturisztikai funkciók többi fürdővárosra jellemző dominanciája. Sopron esetében a város minőségi kulturális programkínálata (közte a Volt Fesztivál) a fó turisztikai termék, miközben az egészségturizmus komplex hatásai a gyógyvízéról és fürdőjéről híres Balf, illetve klimatikus adottságairól nevezetes Lőverek területén érezhető. A nemzetközi jelentőségú fürdővárosok új felosztását a 2.ábra szemlélteti. Kutatásunk során végül hét,

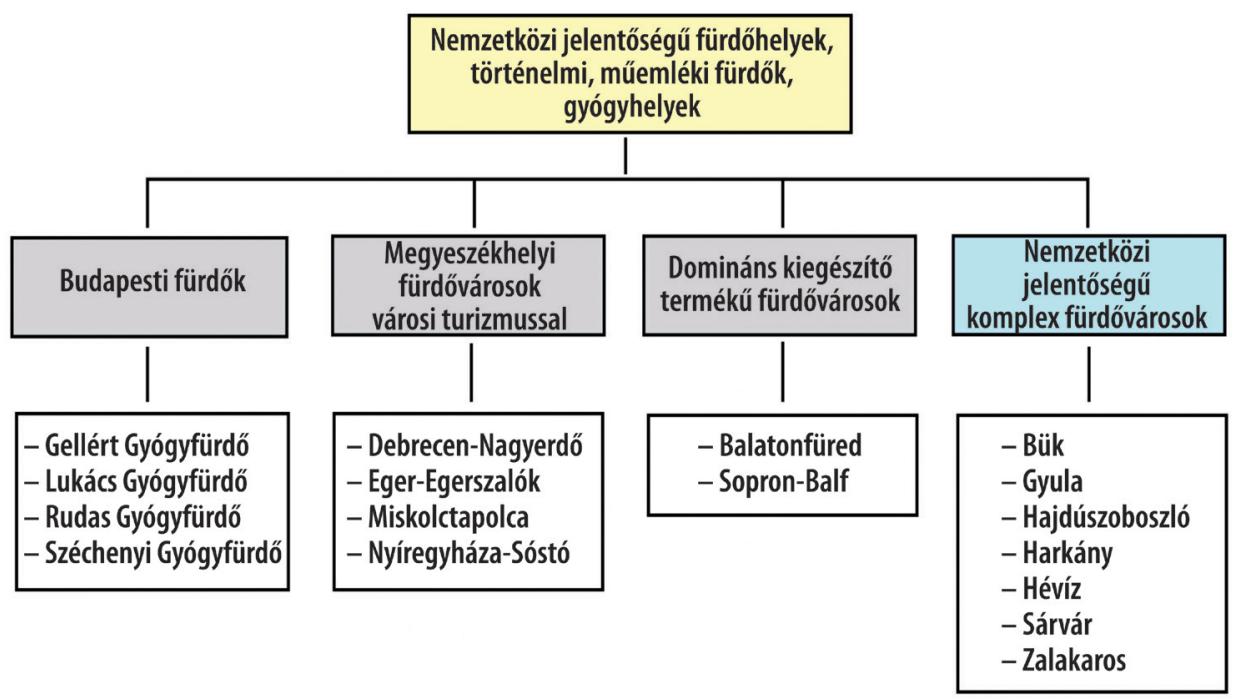

2. ábra Nemzetközi jelentőségú fürdőhelyek újracsoportosítása az OES 2007 alapján (szerk. KöBLi Á. 2018) Figure 2 The re-classification of spas with international significance, based on OES 2007 (ed. by KöBLI, Á. 2018) 
egységes szempontok alapján vizsgálható és fejleszthető fürdőváros került lehatárolásra, amelyek ugyan eltérő mértékben tekinthetők „tisztán” egészségturisztikai profilúnak, mégis a leginkább alkalmasak komplex fürdővárosi vizsgálatok és ebből levonható általános következtetések megvalósítására.

Ezek - név szerint Bük, Gyula, Hajdúszoboszló, Harkány, Hévíz, Sárvár és Zalakaros olyan egészségturisztikai profillal és nemzetközi jelentőségú gyógyfürdővel rendelkező, jelentős vendégforgalmú települések, amelyek esetén a helyi vállalatok és a helyi lakosok döntő többsége közvetlen vagy közvetett módon kapcsolódik az egészségturizmushoz. Jól összehasonlíthatók, a fejlesztési stratégiák alapjai is megegyeznek, mivel hasonló pozitív és negatív hatások érik a helyi társadalmat (KöBLI Á. 2018).

A 3. ábrán látható a kutatás tárgyát képező hét fürdőváros elhelyezkedése és a helyi gyógyászati jellemzőik ismertetése. Teljesen ,tiszta profilú” fürdóvárosnak 5 település - Bük, Hajdúszoboszló, Harkány, Hévíz, Zalakaros - tekinthető, amelyek fejlődésében minden kétséget kizáróan a helyi fürdőkínálat és a kapcsolódó szolgáltatások adták a fó hajtóerőt. Alacsony népességszám mellett az egészségturisztikai funkció dominanciájáról beszélhetünk (MichalKó G.-RÁTz T. 2011), igazi fürdővárosi miliővel, ahol a városi funkciók megjelenése a minőségi egészségturizmusnak köszönhető. Sárvár és Gyula

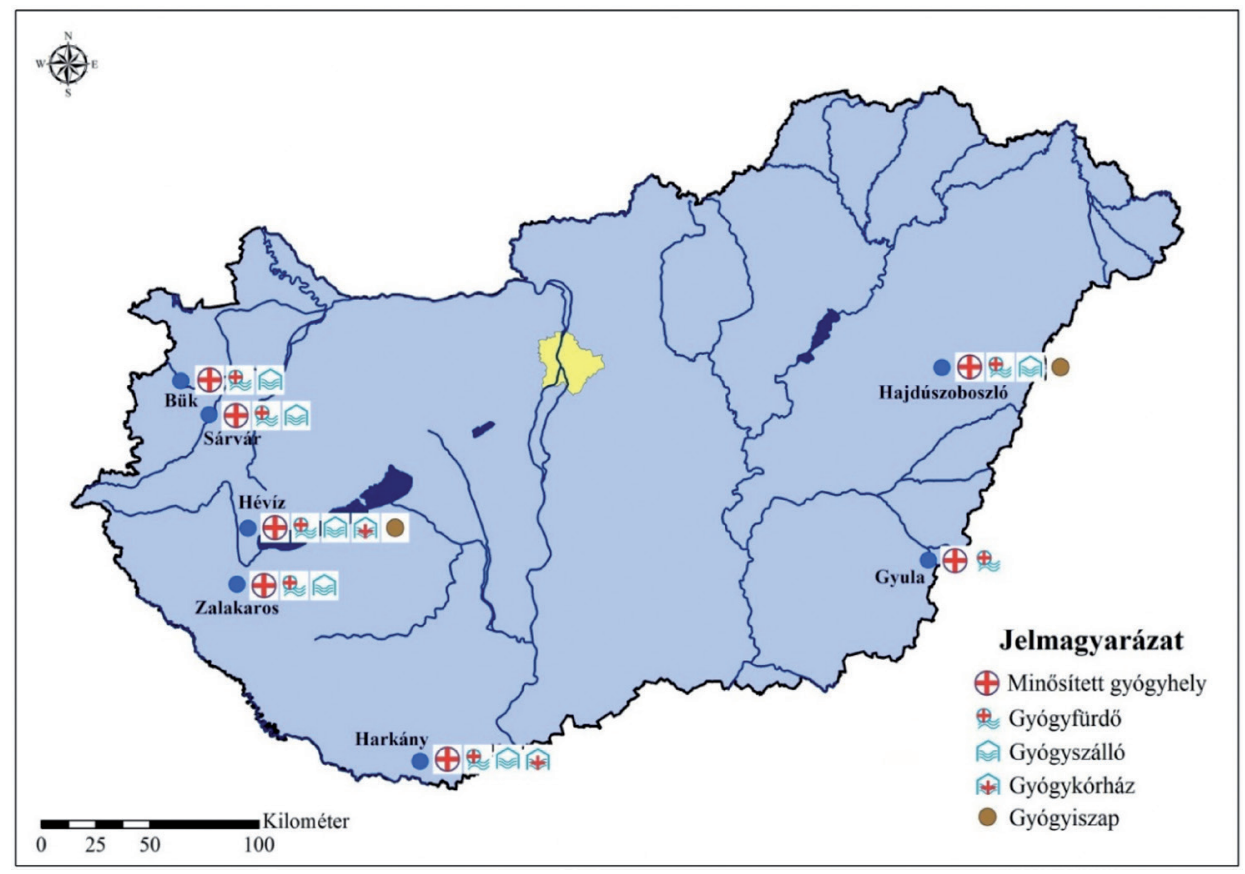

3. ábra Nemzetközi jelentőségú komplex fürdővárosaink elhelyezkedése és gyógytényezői (szerk. HoRvÁTH Z. 2018, az OES 2007 alapján)

Figure 3 The location and medicinal factors of our internationally important spas (ed. by HoRvÁth, Z. 2018, based on OES 2007)

mind gazdasági szerkezete, mind történelmi szerepe és a helyi funkciók kialakulásának tekintetében eltér bizonyos szintig az előbbi településektől, azonban a jelenlegi turisztikai kínálatot, a települések jövőképét, lehetőségeit, problémáit és komplex fejlődését tekintve összehasonlíthatók a másik 5 településsel. 


\section{A vizsgált fürdővárosok jellemzői}

A nemzetközi jelentőségű komplex fürdővárosok közös jellemzői, hogy különleges adottságokkal rendelkeznek. Az attrakció a gyógyvíz és az arra épülő szolgáltatások, amelyek egész évben azonos mértékben és minőségben elérhetők, ezért a többi turisztikai termékhez képest kisebb a szezonalitás mértéke. A munkaerőpiacra pozitívan hatnak, a turizmusból származó bevételek magasabbak, így erős és kiegyensúlyozott gazdasági szerkezet alakul ki a településeken (BAKUCZ M. et al. 2016). A hét fürdőváros stabil vendégkörrel rendelkezik, a turisták motivációja a globális járvány utáni időszakban is meghatározó marad, mivel az egészséges életmód és az alternatív gyógyászat egyre nagyobb szerepet kap a nemzetközi turizmusban. Különösen igaz ez a nyugati országokból érkező idősebb, szenior turistákra. A szenior korosztály mellett egyre több fiatal vendég érkezik preventív, valamint szórakozási, kikapcsolódási céllal a településekre. Az utóbbi években több fürdővárosban új, fizetőképes orosz és cseh vendégkör jelent meg jelentős számban, komoly társadalmi-gazdasági hatásokat keltve a településeken (SzEGEDI A. 2011, KöBLi Á. 2015). A vizsgált fürdők a hazai egészségturizmus és egyben Magyarország jelentős imázsának eszközei belföldön és nemzetközi viszonylatban is (VIZI I. -STRACK F. 2020).

A fürdővárosok magasabb adóbevételekkel rendelkeznek, amit a települési környezet folyamatos fejlesztésére, gondozására lehet fordítani. Rendezett, tiszta település, nagy zöldfelületek és parkok által elegáns és esztétikus városkép alakulhat ki a gyógyhelyeken, ami fontos szerepet játszik a városok arculatában is. A vizsgált települések közül több a turizmusnak köszönhetően jutott városi rangra. A városi cím a vele járó állami támogatás, az európai uniós pályázatok elnyerésének megnövekedő lehetősége segíti az adott település egészségturisztikai infrastruktúrájának kiépülését (MichaLKó G.-RÁTz T. 2011).

A fürdővárosoknak a problémái is hasonlók. A legerősebb negatív hatás a termékek és szolgáltatások magas ára, sok fürdővárosban ugyanis a külföldi vendégek árszínvonalához vannak az árak igazítva. A zsúfoltság és a különböző kultúrákhoz köthető problémák is megjelennek, illetve hosszú távon probléma lehet a természeti erőforrások túlzott igénybevétele (KöBLI Á. 2021).

Hévíz, Harkány, Zalakaros és nagyrészt Hajdúszoboszló településeken egyértelmúen a turizmus és a hozzá kapcsolódó szolgáltatások határozzák meg a gazdasági szerkezetet, a szállodák tekinthetők a legnagyobb helyi foglalkoztatónak. Ezeken a településeken a mikrovállalatok a meghatározók, az iparúzési adó nagy része is a turizmushoz kapcsolódó vállalkozásokhoz köthető. Gyula, Sárvár, illetve Bük esetén viszont jelentős ipari háttér is jelen van, amelynek bevételeire épülve a fürdővárosi szerepkör bővíthető. Az ipar és turizmus viszonya kifejezetten érdekes kérdéskör. Sárvár és Gyula esetén időben előbb alakult ki az ipari bázis, és csak ezt követte a fürdővárosi és turisztikai fejlesztések lehetósége. Bükön pedig a meglévő vasúti kapacitások következtében települtek meg jelentős vállalatok. Fontos, hogy ezeken a településeken a fürdővárosi infrastruktúra (fürdő, szállodák, rekreációs terek, látnivalók) és az ipari infrastruktúra (ipartelep, gyárak, közlekedési és szállítási infrastruktúra) a térben nagyon elkülönülten helyezkedjen el.

\section{Városszerkezeti jellemző́k és sajátosságok}

A vizsgált fürdővárosok esetén a turizmus kimagasló jelentősége nagyban befolyásolja a településszerkezet fejlődését. Az urbanizáció folyamatának változásai, az attrakciók és 
a szálláshelyek bővülése, illetve a turisták térbeli mozgása jelentős társadalmi-gazdasági és környezeti hatásokkal jár együtt.

Az egészségturizmus településszerkezeti hatásai alapján a vizsgált hét nemzetközi jelentôségú fürdőváros esetében az eredmények szerint négy jól elkülöníthető csoport különböztethető meg.

A) Hévíz - Harkány

Egységes és teljes egészségturisztikai profilú települések, ahol az egész városszerkezetre jelentős hatást gyakorol az egészségturizmus minősége és történelmi fejlődése, illetve a turisták jelenléte. A turizmus és gazdaság szempontjából is meghatározó a városközpont szerepe.

B) Hajdúszoboszló - Zalakaros

Az egész település életére elsődleges hatással van az egészségturizmus, a turisták eltéró súllyal, de jelen vannak a város teljes szerkezetében. Azonban a települések fejlődésére jellemző a kétközpontúság, egy önálló turisztikai és egy települési központ létrejötte, ami a földrajzi elkülönülés mellett a funkciók megoszlásában is érvényre jut.

C) Bük

A település lakóterületeitől különálló és sajátosan fejlődő egészségturisztikai terület jellemzi, ahol a fő attrakciók és a kereskedelmi szálláshelyek összpontosulnak. A turizmus mellett az ipar is meghatározó szerepet kap a város életében.

D) Sárvár - Gyula

Nagyobb, összetett városi környezetben a turizmus meghatározó szerepe csak a település egy meghatározott városrészére jellemző, ahol erős szuprastrukturális és szolgáltatásbeli hatásokat okoz. Az attrakciók és szálláshelyek köre, illetve a turisták térbeli mozgása nem érint minden városrészt.

A C) és D) csoport településein meghatározó a jelentős ipari háttér, amely az egészségturisztikai területektől elkülönülve található meg a városszerkezetekben. Az A) és $\mathrm{B}$ ) csoport tisztán egészségturisztikai profilú fürdővárosaiban viszont a gazdasági ágak közül egyértelmúen kiemelkedik a turizmus, amelynek átfogó jellege tükröződik a település fejlődésében is. A hét besorolt fürdővárosból csoportonként egy-egy település jellemzését mutatjuk be részletesen.

\section{A) csoport: Hévíz}

Hévíz egész településére óriási hatással van az egészségturizmus minősége, és az ide érkező turisták kimagasló száma. Hévízen a fő attrakció a Hévízgyógyfürdő és Szent András Reumakórház. A 4. ábra bemutatja, hogy a kereskedelmi szálláshelyek kiterjednek a település meghatározó részére, egy nagyon erős központi csoportosulással a Tófürdő körüli belvárosi utcákban. A térképen nem megjelenített magánszálláshelyek elhelyezkedése (hasonlóan az A) és B) csoport többi településéhez) az egész fürdővárosra kiterjed, így a helyi lakosok a fő látványosságtól távolabbi lakóterületeken is intenzív kapcsolatba kerülnek a turistákkal. A belváros mind a szálláshelyek, mind a turisztikai szolgáltatások és üzletek, illetve a rendezvények szempontjából is központi szerepet tölt be a városszerkezetben. Pozitív tulajdonsága, hogy a vendégek számára minden megtalálható viszonylag kis távolságon belül, egy nagyon komplex, igazi fürdővárosi miliővel rendelkező központ tud kialakulni. Az összpontosulás könnyen átalakulhat zsúfoltsággá, amely a közlekedés szempontjából negatív hatásokkal is jár, így a fejlesztések között komoly súlyt kap a belváros forgalmának csökkentése, a nagyobb központi gyalogos és közösségi terek kialakítása (Hévíz Város Településfejlesztési Koncepciója, 2015). 


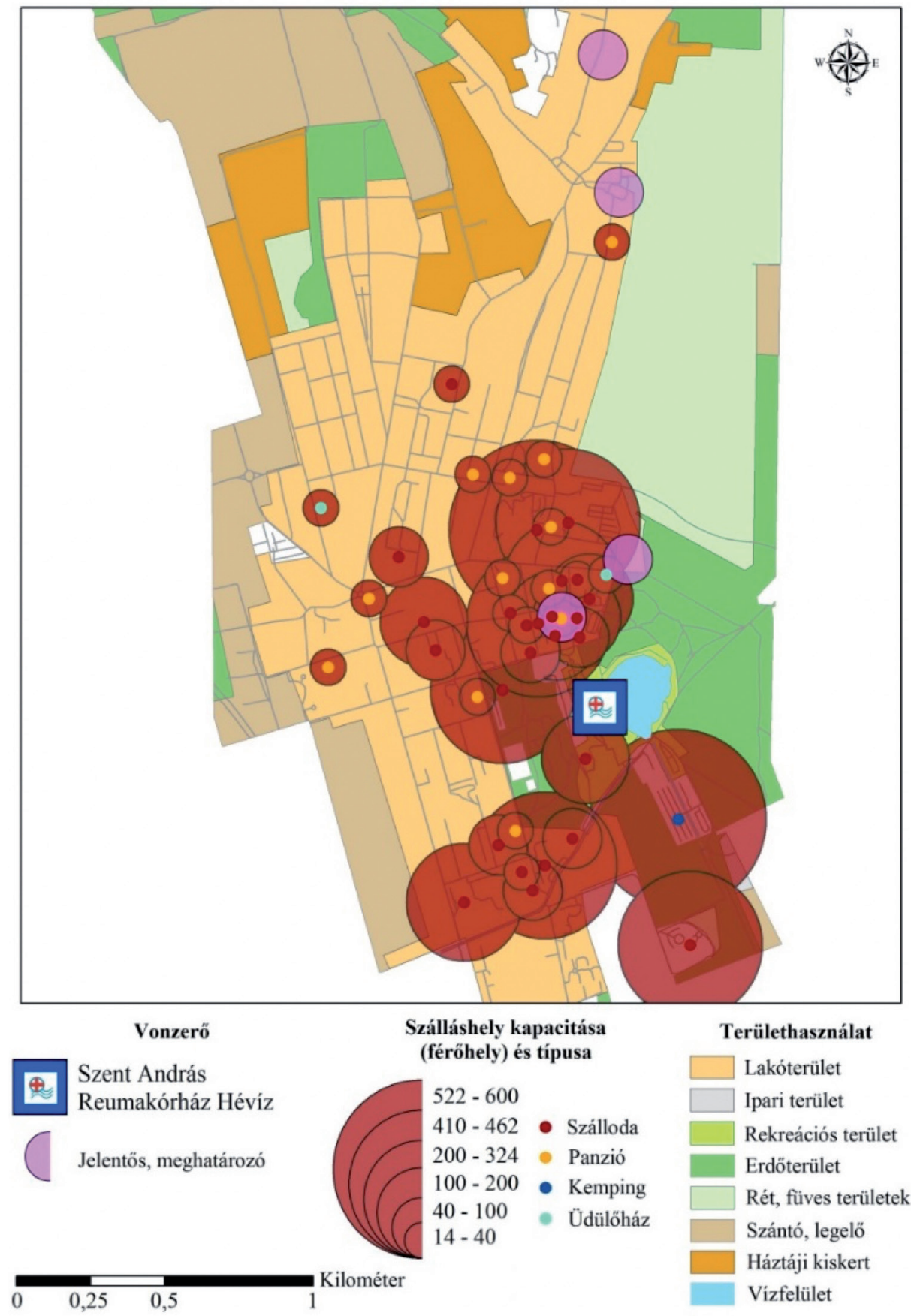

4. ábra Hévíz kereskedelmi szálláshelyeinek és fő vonzerőinek elhelyezkedése a területhasználat függ vényében (szerk. KöBli Á.-HoRváTH Z. 2018, Hévíz szálláshely- nyilvántartása, az OpenStreetMap és a geofabrik.de alapján) Figure 4 The location of commercial accommodations and leading attractions of Hévíz, depending on the land use (ed. by KöBLI, Á.-HoRvÁth, Z. 2018, based on Hévíz accommodation register, OpenStreetMap and geofabrik.de) 
A turisztikai és a lakófunkció együttes megléte számos előnnyel, ugyanakkor konfliktussal is jár, mivel más igényei vannak a helyi lakosoknak (lakhatóság, munkahely, pihenés), és a gyógyulni és élményeket átélni akaró turistáknak (pihenés, szórakozás, gyógyulás). A Hévízi-tó és a körülötte elhelyezkedő Véderdő, a Szent András Reumakórház térségében a nyugalom és az ökológiai védelem kap elsőbbséget. A városközpontot és Tófürdőt érintő környezetterhelés csökkentése kiemelt feladat a jövő fejlesztései során. Hévízen fontos szerepet kapnak a Tófürdő környéki lápok, amelyek egy észak-déli irányultságú, nagyrészt összefüggő ökológiai-zöldfelületi gyűrút alkotnak a beépített területekhez kapcsolódva (Hévízi-tó átfogó tóvédelmi programja 2007).

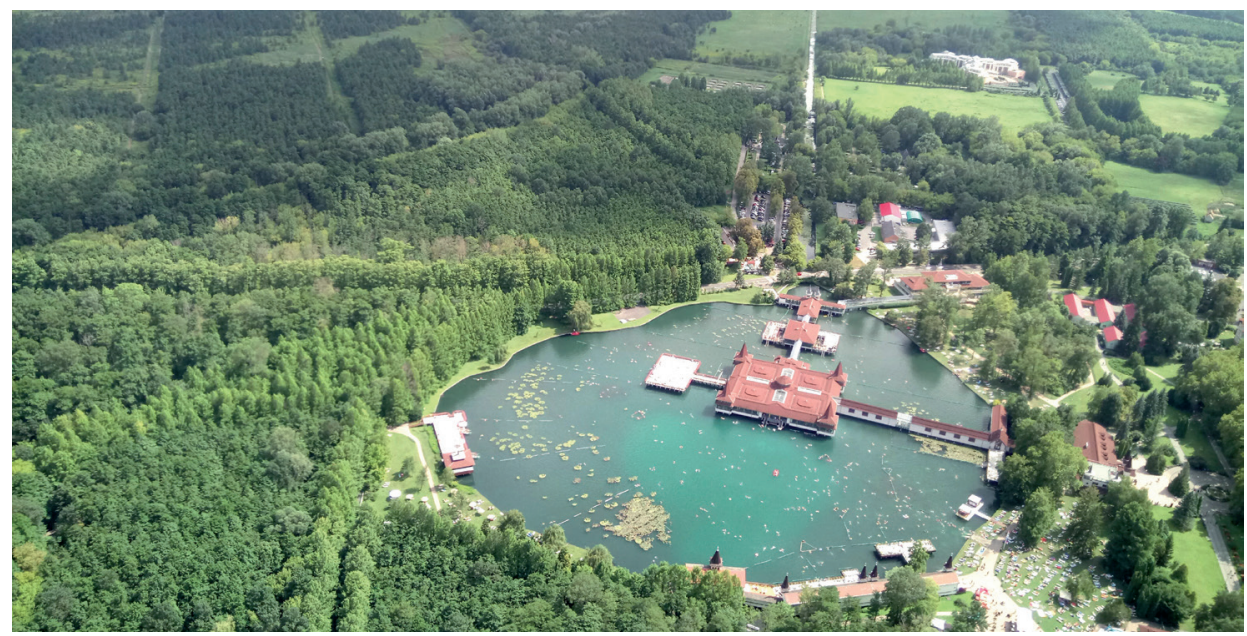

1. kép A Hévízi-tó és a Véderdő övezete (fotó KöBli Á. 2017.

Photo 1 The area of Lake Hévíz and the Protection forest (photo by KöBLi, Á. 2017)

A vendégforgalom igényei újabb és újabb szálláshelyeket követeltek meg és ezzel párhuzamosan új szolgáltatások jelentek meg a városképben. Ennek fő területe a városközpont volt, amely elérte beépítési maximumát. A központtól északra és nyugatra kiterjedt lakóterületek jellemzők, amelyek telítve vannak magánszálláshelyekkel, főleg az északi egregyi városrész irányába futó utcák. Hévíz lakásellátottsága, a lakásállomány komfortfokozata átlagon felüli, az utóbbi 30 évben épült a lakások 65\%-a (Hévíz Város Szerkezeti Terve, 2015). A település- és utcaképet sok helyütt reklámok (magyar, német és orosz nyelven, utóbbi cirill betúkkel) és cégtáblák uralják.

Jövőbeni lehetôség a település északi területeinek fejlesztése mind az attrakciók, mind a lakóterületek és a rekreációs terek szempontjából. Az északi, egregyi városrészben a gasztronómiai (egregyi pincesor) és a kulturális (római kori romkert, Árpád-kori templom és temetô) turizmus adottságai kiemelkedők. Ezt az övezetet a városközponttal főleg magánszálláshelyekkel rendelkező utcák kötik össze, ahol a helyi tömegközlekedés és a városnéző kisvonatok (dottók) játszanak kiemelt szerepet a turisták szállításában (HoRvÁTH Z.-KöBli Á.-Morva T. 2017b).

\section{B) csoport: Hajdúszoboszló}

Hajdúszoboszló egész települési infrastruktúrája érintett a turisták által, főleg a nyári hónapokban, az 5. ábrán azonban látható, hogy a kereskedelmi szálláshelyek alapján 
a fürdő környéki központ (Bánomkert) óriási sűrűsödést mutat. A szállodák nagy része itt található meg, míg a panziók és üdülőházak szerte a környező utcákban. A térképen a magánszálláshelyeket azok elképesztően magas száma miatt nem jelöltük, de a város minden részén található kapacitás, és a vendégforgalom nagyságától és szezonális eloszlásától függően meg is telnek vendéggel a fürdőtől távolabbi vendégházak is.

A közel 900 éves múltú település szerkezetében megtalálhatók a hajdúvárosok jellegzetességei, annak ellenére, hogy az elmúlt évszázadok népességnövekedése következtében a külső kertek fokozatosan beépültek, a területek tovább osztódtak, és új kertek jelentek meg. A város jelenlegi arculatát a 20. század második felében nyerte el, köszönhetően a fürdőkultúra intenzív fejlődésének és a turisztikai szuprastruktúra kialakulásának (Hajdúszoboszló ITS, 2016). A város településszerkezetében meghatározó a kétpólusú felépítés. A városközpont a középkori település belső lakóterületét foglalja magában, ezt veszi körül a külső kertekből kialakult lakóterületek gyűrűje. A rendszert észak-északkeleti irányból alakítja át a turisztikai övezet, amelyet a fürdőkomplexum és a szállodák mellett az óriási számú kereskedelmi szolgáltatók egészítenek ki.

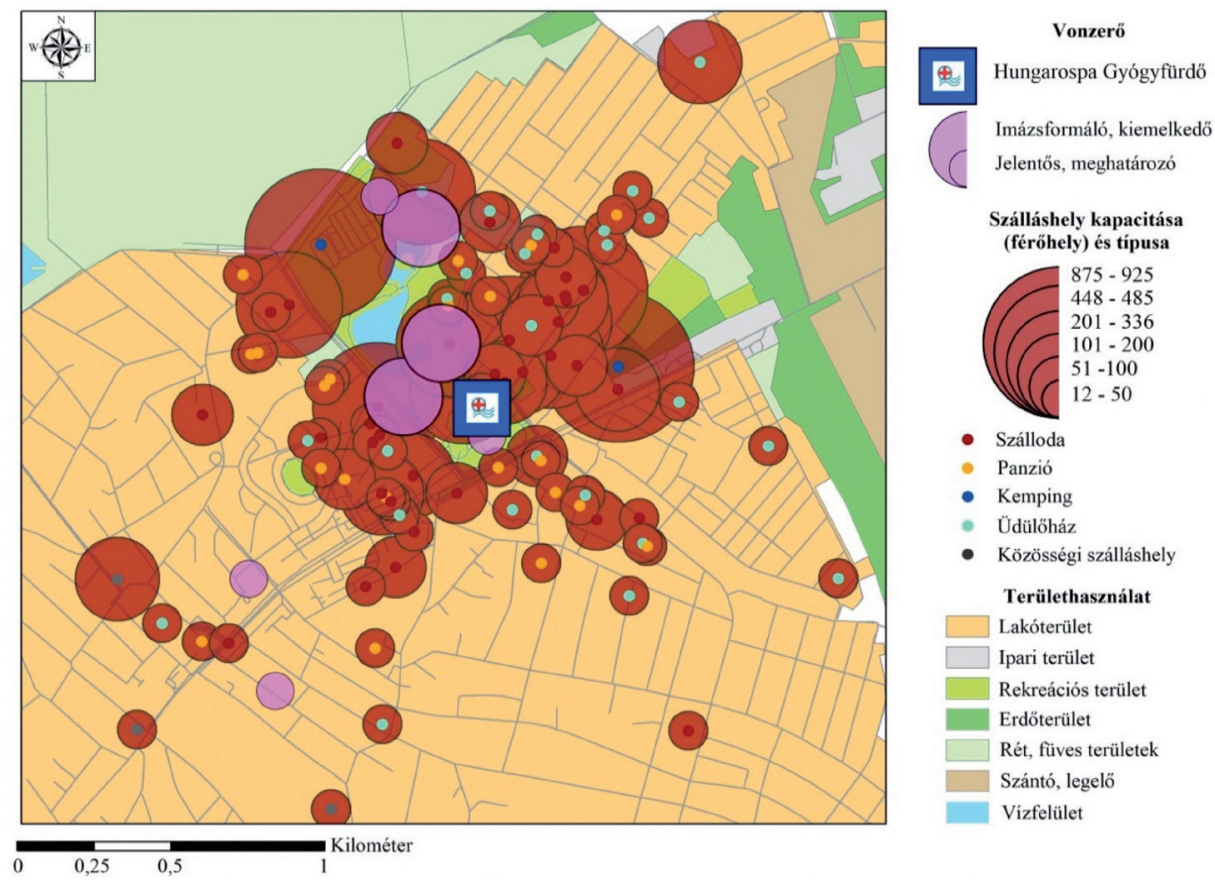

5. ábra Hajdúszoboszló kereskedelmi szálláshelyeinek és fő vonzerôinek elhelyezkedése a területhasználat függvényében (szerk. KÖBLI Á.-HORVÁtH Z. 2018,

Hajdúszoboszló szálláshely-nyilvántartása, az OpenStreetMap és a geofabrik.de alapján)

Figure 5 The location of commercial accommodations and leading attractions of Hajdúszoboszló, depending on the land use (ed. by KöBlı, Á.-HORVÁTH, Z. 2018, based on Hajdúszoboszló accommodation register, OpenStreetMap and geofabrik.de)

Sajátos településszerkezeti övezetet jelent a fürdőtől keletre elhelyezkedő üdülőházas városrész, ahol sok - eredetileg üdülőházként épült - ingatlan ma lakóegységként funkcionál (Hajdúszoboszló ITS, 2016). Az 5. ábrán az átláthatóság következtében nem látszik a település legdélebbi területe, amelynek meghatározó eleme a vasútvonal, ami mentén viszonylag kis kiterjedésú iparterület található. A város déli és nyugati részén, 
a lakóterületektől távolabb elhelyezkedő potenciális iparterületek kiterjedése jelentős, itt a város komoly tartalékokkal rendelkezik, de a városi céloknak megfelelően a jövőben leginkább a turizmust nem veszélyeztető, környezetkímélő iparágak megerősítése a cél (Hajdúszoboszló Gyógyhelyfejlesztési Stratégia 2016-2020).

A kétpólusú szerkezet a funkciómegosztásban is érvényesül. A város északi-északkeleti részén elhelyezkedő Hungarospa Hajdúszoboszló Gyógyfürdő egy olyan, szolgáltatásokkal nagy mennyiségben és magas minőségben ellátott komplex üdülőövezet kialakulását eredményezte, amely a vendégek számára a nyári időszakban ténylegesen központként funkcionál. Ugyanakkor a város földrajzilag központi területe a helyi lakosok számára fontos, a turisták csak alkalomszerúen keresik fel a belvárost. A terület központi funkcióját elsősorban a turisztikai idényen kívül tölti be (Hajdúszoboszló ITS, 2016). A belváros hagyományosan közszolgáltatási központként funkcionál, ahol a közigazgatási, humán szolgáltatási, kereskedelmi és egyéb szolgáltatásokat nyújtó szervezetek tömörülnek.

A város legnagyobb kiterjedésú közösségi célú zöldterülete a Szent István park, ahol emlékmúvek mellett a város jelképének számító köztéri szobrok is találhatók (Harangház). Hajdúszoboszló élhetô város, ahol a településszerkezet komoly fejlődési lehetôségekkel is rendelkezik. Ugyanakkor több városrészben hiányoznak a megfelelő közösségi terek (nyitottak és fedettek egyaránt), hiányos és földrajzilag kiegyenlítetlen a város zöldterületi rendszere, a fürdőtől távolabb eső egyes városrészekben pedig részben hiányoznak a közfunkciójú parkok, kertek. Elsősorban nyáron gyakoriak a közlekedési nehézségek, különösen a parkolás, a túlzsúfoltság és az elérhetőség terén akadnak problémák.

\section{C) csoport: Bük}

Bük településszerkezete sajátos képet mutat a vizsgált fürdővárosok között. A többi településhez képest a lakóterületek és a turisztikai területek területileg élesen elkülönülnek egymástól. Mint az a 6.ábrán is jól látható, a fő attrakciónak számító Bükfürdő Gyógy-és Élménycentrum mellett további attrakciók (Golfpálya, Kneipp és organikus park), illetve a kereskedelmi szálláshelyek nagy része is Bükfürdő településrészen található, míg Bük települési részén a lakóterületek, illetve a kisebb panziók és magánszálláshelyek helyezkednek el. A város nyugati területei az ipari és lakóhelyi funkció színterei. A városi funkciók alapján 4 részre osztható a település. Felső-Bük az ipari létesítményeknek ad otthont, míg Közép-Bük a városi intézményeknek, szociális szolgáltatásoknak. Alsó-Bük bevásárlási funkciókat lát el, a legfontosabb boltok itt találhatók, bár ezek bővítése mind az élelmiszer, mind a ruházati üzletek tekintetében javasolt. A várostól fizikailag is elkülönülő Bükfürdő a turizmus kiemelt színhelye, ahol a turisták igényei alapján történik a városrész fejlesztése (Bük Településfejlesztési Koncepció, 2017).

A legfontosabb fejlesztési kérdés Bükön, hogyan lehetne jobban összekapcsolni a várost és a fürdőterület, illetve, hogy szükséges-e hosszú távon ez a fajta kapcsolat. A Bükfürdő és Bük közti távolság, illetve a fürdő környékének kiépítetlensége előnyt is jelenthet, mivel a fürdő sok más vizsgált fürdővárostól eltérően képes a térben tovább terjeszkedni. Ugyanez igaz a közösségi terek fejlődésére is.

A két városközpont elkülönülése sokkal erősebben érezhető, mint a többi településen. A helyi lakosok számára központi szereppel bíró belváros az elmúlt évtizedben számos funkciót vesztett, különösen a kereskedelmi-gazdasági funkciója gyengült meg, a Bükfürdő városrészben található kereskedelmi és vendéglátóipari decentrum kialakulása miatt (Bük ITS, 2017). A magánszálláshelyek szerepe visszaesett, a turisták pedig még nagyobb arányban csak Bükfürdőn maradnak, ott veszik igénybe a különböző szolgáltatásokat. Bükön kiemelt feladat a belváros új gazdasági fellendítése (Bük Településfejlesztési Koncepció, 
2017). A belvárosban találhatók meg a közigazgatási, közszolgáltatási és kulturális funkciók. Bük modern kisváros, amely kevés múemlékkel rendelkezik. Míg más városokban a múemlékek védelme kulcsterület, Bük olyan fejlesztéseket hozhat létre, ami sok évtized múlva lehet majd büszke öröksége a városnak.

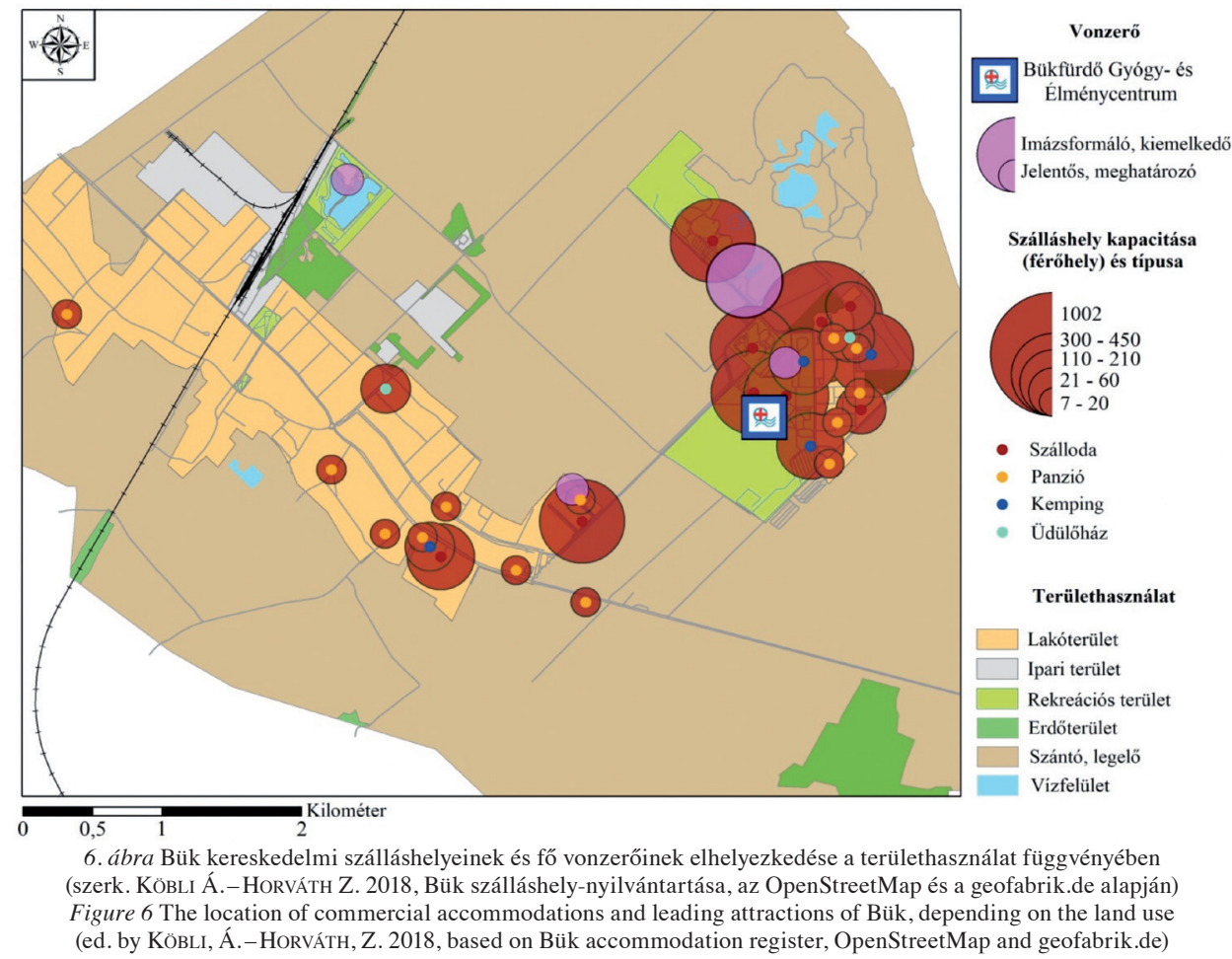

Bükfürdő területét leginkább mezőgazdasági területek veszik körbe, igen sajátos atmoszférát teremtve a szállodáknak, a hotelszobák egy része ugyanis közvetlenül a szántóföldekre néz. A jövőbeni fejlesztéseknél a fürdő környezetének további parkosítása, zöldterületekkel történő bővítése, egy élhetó és esztétikus véderdő kialakítása fontos lehetôség és cél.

Bük erős gazdasági háttérrel rendelkezik, a turizmus sikere mellett az ipar szerepe is meghatározó, Bük munkaerővonzása Szombathelynél is kedvezőbb (Bük Településfejlesztési Koncepció, 2017). Az ipar és az abból származó bevételek kiemelt helyet töltenek be Bük települési és turisztikai fejlődésében is.

\section{D) csoport: Sárvár}

Sárvár meghatározó történelmi és gazdasági szerepe után napjainkban egyértelmúen egészségturizmusának köszönheti a fejlődését. A 7. ábrán jól látható, hogy legfontosabb turisztikai központ a sárvári Gyógy- és Wellnessfürdő környezete, az úgynevezett Fürdőnegyed és rekreációs zóna, ahol a két legnagyobb befogadóképességú szálloda mellett több kisebb kereskedelmi szálláshely, illetve több meghatározó attrakció (Csónakázó-tó, Kalandpark) is megtalálható. A kisebb szállások ezen kívül, a történelmi belváros környé- 
kén összpontosulnak, utóbbinak kiemelt attrakciója a sárvári Vár. A két területet összekötő út meghatározó kereskedelmi és szolgáltatásbeli szereppel rendelkezik, a turisták által legintenzívebben használt terület (Sárvár ITS, 2015). A szálláshelyek elhelyezkedése alapján meghúzható egy elméleti határvonal, a látnivalóktól nyugatra eső területen ugyanis már sem szállások, sem turisták nem igazán találhatók. Ily módon a térben a turisták és a helyiek városrészek szerint jól elkülönülnek egymástól.

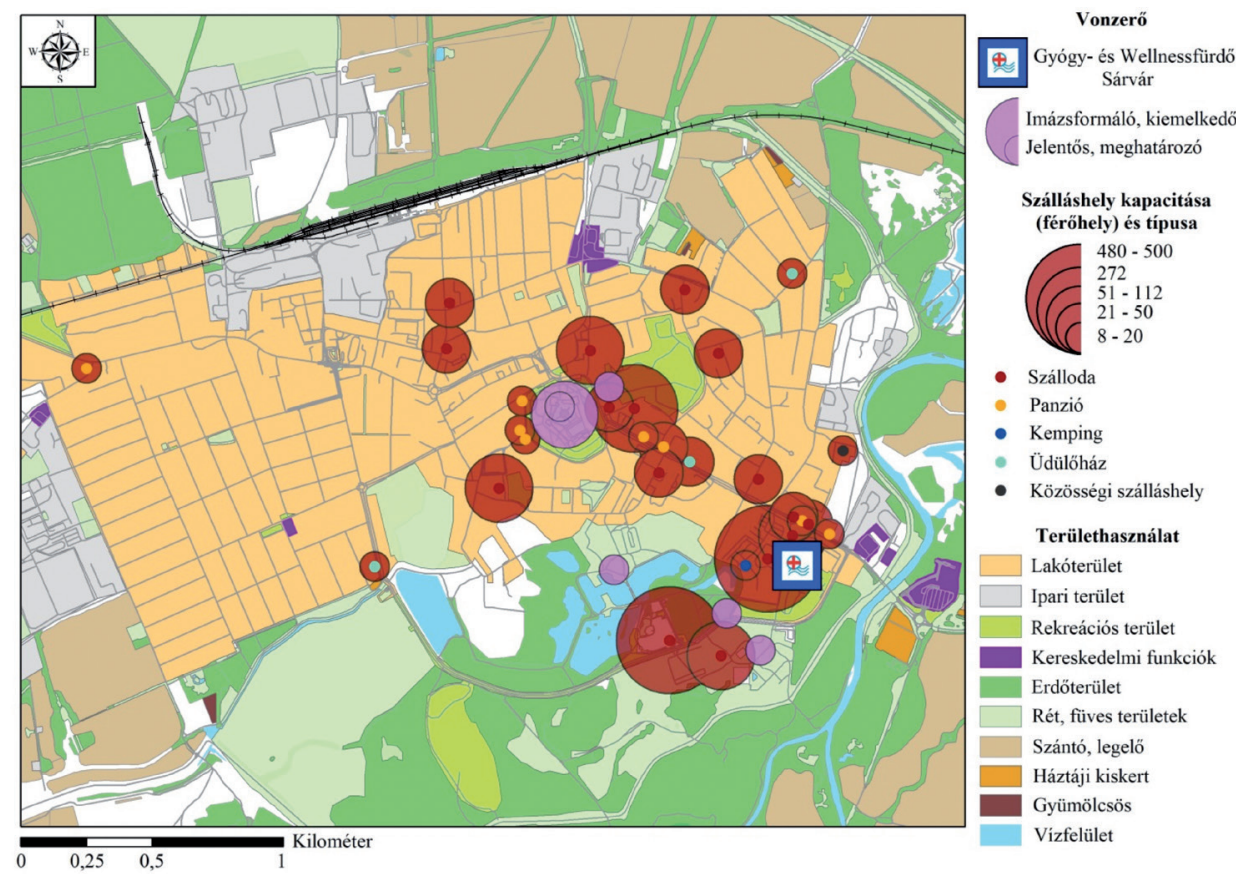

7. ábra Sárvár kereskedelmi szálláshelyeinek és fő vonzerőinek elhelyezkedése a területhasználat függvényében (szerk. KöBli Á.-HoRvÁTH Z. 2018, Sárvár szálláshely-nyilvántartása, az OpenStreetMap és a geofabrik.de alapján) Figure 7 The location of commercial accommodations and leading attractions of Sárvár, depending on the land use. (ed. by KöBli, Á.-HoRVÁTH, Z. 2018, based on Sárvár accommodation register, OpenStreetMap and geofabrik.de)

Sárvár fürdővárosában az ipar kitüntetett szerepet tölt be. A 7.ábrán jól láthatók az északi és nyugati ipari területek, amelyek nagy szerepet töltenek be a város életében, földrajzilag messze elkülönülve a fürdő övezetétől. A fürdőtől keletre eső ipari és kereskedelmi területeken a jövőben várhatóan turisztikai fejlesztések valósulhatnak meg kedvező fekvésük miatt, míg az ipar a távoli városrészeken fejlődhet tovább (Sárvári Gyógyhelyfejlesztési Stratégia, 2014).

A városközpont kiemelt szerepet tölt be a város életében, történelmi emlékeivel és közigazgatási szerepével. Külön ki kell emelni a déli rekreációs zóna területét, amely a fürdőtől délre fekvő erdős és füves területekkel a térképen is jól látható. A településrész a fürdő közvetlen szomszédságában a városközponttól délre húzódó, nagy kiterjedésú Rába menti és a kapcsolódó természetközeli ökológiai területeket foglalja magába. A város közigazgatási területén fennmaradt holtágak erôsen eltéró állapotúak, és sokféle igénybevételnek kitettek. Értékük, különösen a nyílt vízzel rendelkező holtágak esetében nemcsak természetvédelmi, hanem mezőgazdasági, rekreációs és környezetvédelmi szempontból is kiemelkedő (Sárvár ITS, 2015). 


\section{Összefoglalás}

A nemzetközi jelentőségú hazai fürdővárosok komplex vizsgálata fontos terület, hiszen az egészségturizmus fejlesztése nagy súlyt kapott az utóbbi években, miközben a járványügyi krízist követő újra nyitás során is kiemelt szerephez jutnak majd ezek a települések. A különböző vizsgálatok alapján megállapítható, hogy a gyógyfürdők részben alkalmasak arra, hogy urbanizáljanak egy egész települést, több hazai fürdőhely (a vizsgált nemzetközi jelentőségú Bük és Zalakaros, illetve a vizsgálatba be nem vont, de a hazai fürdőtelepülések nagy részét adó kisebb üdülőhelyek) esetén hiányos központi funkciójú, és aránylag kis népességú városokat alakítanak ki. Az elemzett fürdővárosok egy része (Hévíz, Hajdúszoboszló, Harkány, Zalakaros) meghatározóan a turizmusra, mint fó gazdasági ágazatra épít; az ô esetükben szükséges a helyi egészségturisztikai kínálathoz jól illő, kiegészítő turisztikai és szolgáltatások fejlesztése, valamint a helyi erőforrásokon alapuló tudatos tervezés. Az egészségturizmus infrastruktúrája, a fürdő és környezetük, a rekreációs közösségi terek jelenléte egyértelmúen növeli a városkép minőségét, a városi életérzést.

A vizsgált fürdővárosok közül több (Sárvár, Gyula, Bük) jelentős ipari háttérrel rendelkezik, amelynek bevételeit alapvetôen a helyi turizmus és a város fejlesztésébe építhetik be, megteremtve a gazdasági stabilitást. Az egészségturisztikai piac újabb szereplői, a közelmúltban jelentôs fejlesztéseken átesett fürdővárosok - mint például Sárvár - számára a gyógyhelyfejlesztés szempontjából optimálisabb út a turizmus és ipar közös, tudatos fejlesztése, mivel így olyan komplex fejlesztésre alkalmas bevételekre tehetnek szert, amelyeket kizárólag a fürdó, valamint a turisztikai szolgáltatók nem tudnak kitermelni. Természetesen kiemelt szinten figyelni kell a fürdővárosok érzékeny természeti környezetére, a vízbázisok védelmére, ezek állapotát semmilyen ipari és gazdasági tevékenység vagy érdek nem veszélyeztetheti. A bemutatott fürdővárosok településszerkezeti kialakulását sok egyedi tényező - kiinduló településméreti különbségek, vízbázisok elhelyezkedése, kiegészítő turisztikai adottságok megléte stb. - alakította folyamatosan, ennek ellenére a legtöbb hazai gyógyfürdôvel rendelkező kisebb település szempontjából is értékes mintaterületnek tekinthetők a legsikeresebb hazai fürdőhelyek településszerkezeti példái és fejlődési folyamatai.

Természetesen az eredmények a járvány okozta korlátozások elôtti állapotot mutatják be, ezzel ki is jelölve a kutatás további irányát. Mindenképp szükséges lesz a korlátozások utáni években a kutatás megismétlése és egy összehasonlító vizsgálat elvégzése, ami majd pontosan megmutatja, mely területeken és milyen módon változtak akár pozitív, akár negatív irányba a legnépszerűbb hazai fürdővárosok településszerkezeti sajátosságai, az új fejlesztések miként illeszkedtek be az adott település szövetébe és hogyan alkalmazkodtak az érzékeny természeti környezet védelmét megcélzó településfejlesztési irányvonalakhoz.

KÖBLI ÁDÁM

Edutus Egyetem, Gazdálkodástudományi Tanszék, Budapest

kobli.adam@edutus.hu

HORVÁTH ZOLTÁN

PTE Földtudományok Doktori Iskola, Pécs

hozool@gmail.com 


\section{IRODALOM}

BAKUCZ M.-TEGZES A. 2016: Fürdőtelepülések versenyképességi vizsgálata néhány magyar és közép-európai régióban. - OTKA 106283. sz. „Gyógy- és termálfürdőhelyi versenyképességi tényezők felmérése hazai és közép-európai régiókban” címú alapkutatás záró monográfia. Pécsi Tudományegyetem, Pécs. 188 p.

BAKuCZ M.-KÖBLi Á.-HajnAL K. 2016: A gyógy-és termálturizmus versenyképessége néhány közép-európai régióban. - Földrajzi Közlemények 140. 4. pp. 376-393.

Budapest Főváros Kormányhivatalának országos nyilvántartása az engedélyezett gyógyszállókról. www.kormanyhivatal.hu/download/e/26/06000/6_Gyogyszallok_002.pdf

Bük Gyógyhelyfejlesztési stratégia 2016: „Élményteli gyógyhely: Bükfürdo”’. - HHP Contact Tanácsadó Kft. 60 p.

Bük Város településfejlesztési koncepciója és településrendezési terve 2017. V. Integrált Településfejlesztési Stratégia. - Dexinvest Magyarország Kft. 88 p.

CSIFFÁRY G. 2004: Régi magyar fürdővilág. - Helikon Kiadó, Budapest. 139 p.

Galambos I.-Michalkó G.-TörzsöK A.- Wirth G. (szerk.) 2015: Fürdővárosok (TITE könyvek 7.) - Történelmi Ismeretterjesztő Társulat Egyesület - Magyar Földrajzi Társaság, Budapest. 292 p.

Hajdúszoboszló Gyógyhelyfejlesztési Stratégia 2016-2020. 2016. - Budai és Társa Tanácsadó Kft. 70 p.

Hajdúszoboszló Város Integrált Településfejlesztési Stratégiája 2016. - MEGAKOM Tanácsadó Iroda. 216 p.

HAJNAL K. 2010: Itt és most: helyi megoldások a globális válságra. - Zöld Völgyért Egyesület, Bükkösd. $105 \mathrm{p}$.

Hévíz Város Szerkezeti Terve 2015. - Hübner Tervező Kft. 19 p.

Hévíz Város Településfejlesztési Koncepciója 2015. - Hübner Tervező Kft. 56 p.

Hévízi-tó átfogó tóvédelmi programja - előkészítő tanulmánya 2007. - Balatoni Integrációs és Fejlesztési Ügynökség Kht. - VITUKI Környezetvédelmi és Vízgazdálkodási Kutató Intézet Kht., a Magyar Állami Földtani Intézet közremúködésével. 94 p.

HoRvÁth Z.-KöBLi Á. 2016: Az együttmúködés lehetőségei és kockázatai két szomszédos fürdőváros példáján. - In: Berghauer S. (szerk.) Társadalomföldrajzi kihívások és adekvát válaszlehetőségek a XXI. század Kelet-Közép-Európájában. Nemzetközi Földrajzi Konferencia. II. Rákóczi Ferenc Kárpátaljai Magyar Fơiskola. pp. 511-518.

Horváth Z.-KöBli Á.-MorvA T. 2017a: Az egészségturizmus hatása a települések életére - településmorfológiai vizsgálatok Kehidakustányban. - Településföldrajzi Tanulmányok 6. 1. pp. 41-55.

Horváth Z.-KÖBLi Á.-MoRvA T. 2017b: A turizmuskutatás perifériáján. A hazai városnéző kisvonatok turisztikai szerepének és desztinációnkénti jellegzetességeinek vizsgálata térinformatikai (GIS) módszerekkel. - Turizmus Bulletin 17. 3-4. pp. 4-12.

Hustiné BÉRES K. 2011: Fürdők és az egészségturizmus közgazdaságtana. - Szent István Egyetem. 107 p. http://www.tankonyvtar.hu/hu/tartalom/tamop412A/2010-0019_Furdok_es_az_egeszsegturizmus_kozgazdasagtana/ch02.html

JónÁS-Berki M.-CSAPÓ J.-PÁLfi A.-Aubert A. 2014: A market and spatial perspective of health tourism destinations: the Hungarian experience. - International Journal of Tourism Research 17. 6. pp. 602-612.

Kósa L. 1999: Fürdóélet a Monarchiában. - Holnap Kiadó, Budapest. 272 p.

KöBLI Á. 2015: Russian tourist in Hévíz: following the way of Karlovy Vary? - Acta Geographica Universitatis Comenianae 59. 1. pp. 35-51.

KöBLI Á. 2018: Nemzetközi jelentőségű fürdővárosaink komplex fejlesztési lehetőségei a fenntarthatóság jegyében. - PhD-értekezés. PTE TTK Földtudományok Doktori Iskola. Pécs. 234 p.

KöBLI Á. 2021: A helyi lakosok életminőségének vizsgálata a magyar fürdővárosokban. - Modern Geográfia 16. pp. 37-58.

Michalkó G.-RÁTz T. 2011: Egészségturizmus és életminőség Magyarországon: fejezetek az egészség, az utazás és a jól(1)ét magyarországi összefüggéseiről. - MTA Földrajztudományi Kutatóintézet, Budapest. $179 \mathrm{p}$.

Nemzeti Turizmusfejlesztési Stratégia 2030 (NTS) 2017. - Magyar Turisztikai Ügynökség. http://www.kormany.hu/download/8/19/31000/mtu_kiadvany_EPUB_297x210mm\%20-\%20preview.pdf

Országos Egészségturizmus Fejlesztési Stratégia (OES) (2007-2013) 2007 - Aquaprofit Rt. Budapest. 173p. http://www.kormany.hu/download/b/8e/20000/Egeszsegturizmusstrategia.pdf

PuczKó L.-RÁTz T. 2001: A turizmus hatásai. - Aula Kiadó, Budapest. 482 p.

Sárvár Integrált Településfejlesztési Stratégia 2014-2020. 2015. - Fülöp Építésziroda Bt. 77 p.

Sárvári Gyógyhelyfejlesztési Stratégia 2014-2020. - AQUAPROFIT. 92 p.

Sмiтн, M.-Puczkó L. 2010: Egészségturizmus: gyógyászat, wellness, holisztika (Turizmus Szakkönyvtár). - Akadémiai Kiadó, Budapest. 427 p. 
Szegedi A. 2011: Az orosz piacban rejlő turisztikai lehetőségek. - V. Magyar-Orosz Nemzetközi Gazdasági Fórum és Üzletember-találkozó, 2011. február 24-25.

http://docplayer.hu/3496773-Az-orosz-piacban-rejlo-turisztikai-lehetosegek-szegedi-andrea-kepviseletvezeto-magyar-turizmus-zrt-moszkvai-kepviselete.html

Vizi I.-STRACK F. 2020: A Lenti termálfürdő vendégelégedettségi vizsgálata a földrajzi térrel összefüggó egészségturisztikai termékfejlesztés stratégiai időszakában. - Földrajzi Közlemények 144. 1. pp. 79-95.

ZsARNóCZKY M. B. 2017: Az egészségturizmus folyamatainak vizsgálata észak-magyarországi mintaterületeken. - Doktori (PhD) értekezés. Enyedi György Regionális tudományok Doktori Iskola, Szent István Egyetem. Gödöllő. 138 p. 